\title{
POTENTIAL OF WATER HYACINTH (EICHHORNIA CRASSIPES L.) FOR PHYTOREMEDIATION OF HEAVY METALS FROM WASTE WATER
}

\author{
*NAZIR MI ${ }^{1}$, *IDREES I ${ }^{2}$, DANISH P $^{1}$, AHMAD ${ }^{3}$, ALI $Q^{1}$, MALIK A ${ }^{1}$ \\ ${ }^{1}$ Institute of Molecular Biology and Biotechnology, The University of Lahore, Lahore, Pakistan \\ ${ }^{2}$ Department of Chemical Engineering, COMSATS University of Information and Technology, Lahore, Pakistan \\ ${ }^{3}$ Institute of Agricultural Sciences, University of the Punjab, Lahore, Lahore, Pakistan \\ Corresponding author: muhmmadirtaza@gmail.com, ijlalidrees2@gmail.com
}

(Received, $9^{\text {th }}$ February 2020, Accepted $24^{\text {th }}$ April 2020)

\begin{abstract}
The present study was carried out to determine the potential for phytoremediation of water hyacinth (Eichhornia crassipes) plant for Cadmium (Cd), Arsenic (Ar), and Mercury (Hg) absorption. The samples were collected from Dhamthal, Zafarwal and Narowal. The plant samples were cut into their parts and dried at room temperature for 25-30 days until they were fully dried. The change in fresh weight and dry weight was examined. The data of collected samples was recorded and statistically analyzed, which revealed the significance of results for different localities. The lower coefficient of variation was recorded for all studied traits which revealed that there was consistency among the results for different localities. For our study the plant's percentage removal of metals was determined using atomic absorption spectroscopy in plant sample as well as water sample. Metal uptake happened at variable degrees. The water hyacinth uptake the largest metal uptake per dry weight of water hyacinth was $166.25 \mathrm{ppm}$ for cadmium and the smallest 0.032ppm was for mercury. In water sample highest amount of metal was 177.25ppm for cadmium and lowest 0.012ppm was for arsenic. It was found from our study that the water hyacinth (Eichhornia crassipes) uptake cadmium (cd) metal from sewage water in highest amount as compare to arsenic and mercury. It was suggested that the use of water hyacinth plant may be helpful to remove heavy metals from waste water to minimize the heavy metal pollution of water.
\end{abstract}

Keywords: Water hyacinths, phytoremediation, cadmium, arsenic, mercury

\section{Introduction}

Our earth contains over $70 \%$ of water. The humanaccessible freshwater measure is only $0.01 \%$ and the rest being bound in ice (Ahmed et al., 2015). This little extent of the earth's absolute water is ending up progressively contaminated because of different anthropogenic exercises like unpredictable transfer of civil and mechanical waste and enormous scale utilizations of synthetics in agriculture (Soomro et al., 2011; Zubair et al., 2016). Many substances have been registered as poisons in freshwater and incorporating acids such as alkali, anions (e.g. sulfide, cyanide) household wastewater and homestead compost, chlorine gases, heavy metals (cadmium, arsenic, mercury) supplements (phosphates, nitrates) oil and oil fumes etc. Heavy metals are hard to expel from amphibian environment since they are non-degrade able. There are numerous procedures present that evacuate heavy metals but they all are costly. Therefore, it is necessary to develop such systems which are eco-accommodating and financially savvy for getting the waste metals expel from the environment (Erakhrumen and Agbontalor, 2007; Idrees et al., 2017). Phytoremediation is a technology in which eliminates dangerous substances from the environment with the help of plants and micro organisms that present soil. Heavy metals take up by the plant through phytoremediation innovations is utilizing these instruments of phytoextraction, phytostabilisation, rhizofiltration, and phytovolatilization (Dushenkov, 2003). Phytoextraction is the take-up / ingestion and translocation of contaminants by plant roots into the plant shoots over the ground (Rulkens et al., 1998). Phytostabilization is the use of certain plant species to immobilize contaminants from soil and groundwater through ingestion and root adsorption process (Ghosh and Singh, 2005). Rhizofiltration is the adsorption or precipitation on plant roots or ingestion in the fundamental foundations of contaminants that are arranged to clean up simultaneous wastewater that covers the root zone (Salt et al., 1995). Phytovolatilization is the uptake

[Citation: Nazir, M.I., Idrees, I., Danish, P., Ahmad, S., Ali, Q., Malik, A. (2020). Potential of water hyacinth (Eichhornia crassipes L.) for phytoremidation of heavy metals from wastewater. Biol. Clin. Sci. Res. J., 2020 : 6. doi: https://doi.org/10.54112/bcsrj.v2020i1.6] 
contaminants and convert into volatile compounds and ispersed in the air with the help of stomata (Ghosh and Singh, 2005). Phytodegradation includes the breakdown of complex natural mixes into more straight forward structure and these substances present into plant tissues (Chaudhry et al., 1998). There are 400 types of hyperaccumulators use for the phytoremediation procedure e.g A. racemouses, Zea mays, Eichhornia crassipes etc. The Eichhornia crassipes is the most idealistic oceanic plant. The water hyacinth (Eichhornia crassipes) assume a significant job in the phytoremediation of poisons like cadmium, arsenic, cobalt, nickel, mercury and lead from antiquated time to present day era (Idrees et al., 2017). It becomes quick with no exceptional requirements. The different sorts of sea-going plants are helpful but the water hyacinth has capacity to remediate numerous kinds of substantial metals. Therefore, in this investigation utilize this plant (Téllez et al., 2008). In this paper the principle spotlight was on examining the phytoremediation productivity of water hyacinth in expelling heavy metals like mercury, cadmium and arsenic from the waste water.

\section{Material and methods}

This study was conducted to investigate the metal uptake capacity of water hyacinth on heavy metals like Lead, Arsenic, Cadmium, Mercury etc. The water hyacinth (Eichhornia crassipes) plants used in the study were obtained from the different local areas of Narowal, Punjab Pakistan. Narowal is situated at northeast side of Punjab. The sample of water hyacinth collects from 3 different local areas of Narowal. From one area take 3 healthy plants with roots and water in the plastic bottle as a sample to check the water quality, water contaminants and presence of heavy metals before and after the experiment. According to this procedure, obtained 9 plants sample and 3 water sample and numbering the sample according to the area. Unwanted debris like insects larvae, dust particles and other epiphytes were removed from the plants before being washed by the water. Than weight the water hyacinth on weight balance and measuring the length of plant by measuring scale. After this procedure, separate the plant leaves, stem and root with surgical blade and then weight all the parts of the plant separately. After this, plants allow to dry under the room temperature until all the separates parts were fully dried. The data was collected for various seedling morphological traits; plant height $(\mathrm{PH})$, stem/root fresh weight ratio (SRFWR), stem/root dry weight ratio (SRDWR), root moisture percentage (RM\%) and stem moisture percentage (SM\%). The data was statistically analyzed through analysis of variance techniques by using Statistix8.1 software. After this procedure, one dry plants sample and water sample from each location selected and evaluate the metal concentration through atomic absorption spectroscopy. The results was shown in the graph for compare the metals concentrations among different localities.

\section{Results and discussions \\ Plant Height}

The average plant height under all studied treatments was recorded as $35.244 \pm 0.2388 \mathrm{~cm}$. The lower value of coefficient of variation was $1.17 \%$ (Table 1 ). The results indicated that the higher plant $(37.033 \mathrm{~cm})$ under locality Narowal and, locality Dhamthal $(36.100 \mathrm{~cm})$ and was found while lowest plant was for control $(32.600 \mathrm{~cm})$ under locality Zafarwal (Figure 1). Plant heights vary according to different localities. The higher plant height indicated that the growth of hyacinths was higher which leads towards the increase in plant height because of higher photosynthetic rate under available nutrient resources in water. The accumulation of organic and inorganic compound was higher which indicated that the accumulation of heavy metals may also be higher in stem of hyacinths plants (Ingole and Bhole, 2003; Mahmood et al., 2005).

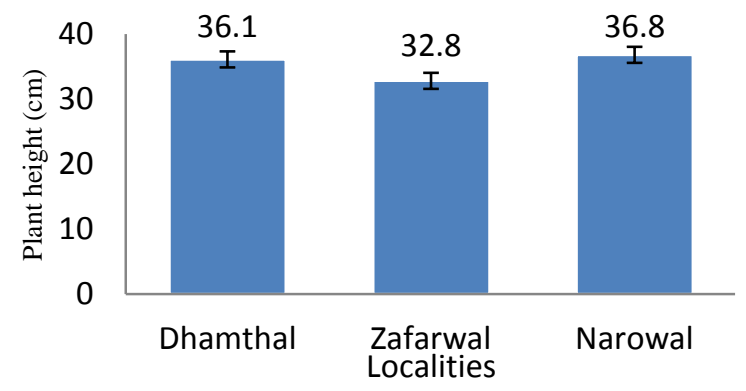

\section{Figure 1. Plant height of water hyacinth under} different localities

\section{Stem/root fresh weight ratio}

It was found from results that the average stem/root fresh weight ratio under all studied treatments was recorded as $0.3478 \pm 0.001925$. The lower value of coefficient of variation $(0.96 \%)$ for stem/root fresh weight ratio indicated that there was consistency among the results which also cleared that the results were reliable for plant of water hyacinth under different localities (Table 1). In Dhamthal fresh weight ratio was (0.29) in Zafarwal fresh weight ratio was (0.53) and in Narowal weight ratio is (0.22) (Figure 2). The higher stem/root fresh weight ratio indicated that the amount of absorbed moisture contents was higher in stem and roots. The higher ratio revealed that the hyacinths plants may survive under harsh conditions because of higher storage ability of stems and roots (Dushenkov, 2003; Idrees et al., 2017; Rulkens et al., 1998).

[Citation: Nazir, M.I., Idrees, I., Danish, P., Ahmad, S., Ali, Q., Malik, A. (2020). Potential of water hyacinth (Eichhornia crassipes L.) for phytoremidation of heavy metals from wastewater. Biol. Clin. Sci. Res. J., 2020 : 6. doi: https://doi.org/10.54112/bcsrj.v2020i1.6] 


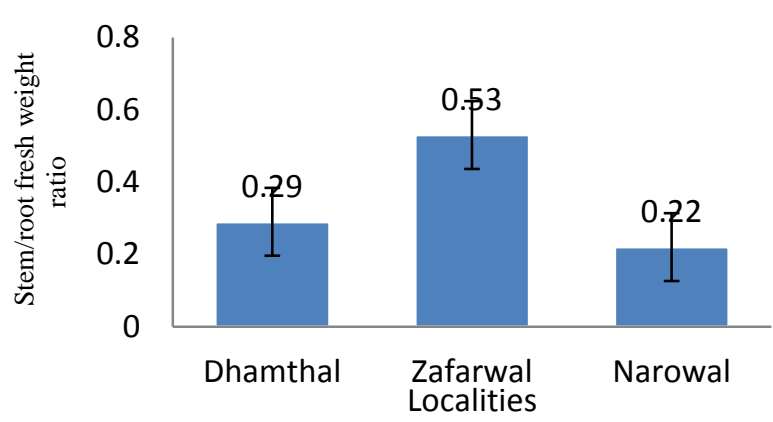

Figure 2. Stem/root fresh weight ratio of water hyacinth under different

\section{Stem/root dry weight ratio}

It was found from results that the average stem/root dry weight ratio under all studied treatments was recorded as $0.3769 \pm 0.00419$. The lower value of coefficient of variation (1.93\%) for stem/root dry weight ratio indicated that there was consistency among the results which also cleared that the results were reliable for plant of water hyacinth under different localities (Table 1). In Dhamthal dry weight ratio is (0.31) in Zafarwal dry weight ratio is (0.4) and in Narowal dry weight ratio is (0.39) (Figure 3). The higher ratio revealed that the hyacinths plants may survive under harsh conditions because of higher storage ability of stems and roots (Carbonell et al., 1998; Idrees et al., 2017; Soomro et al., 2011).

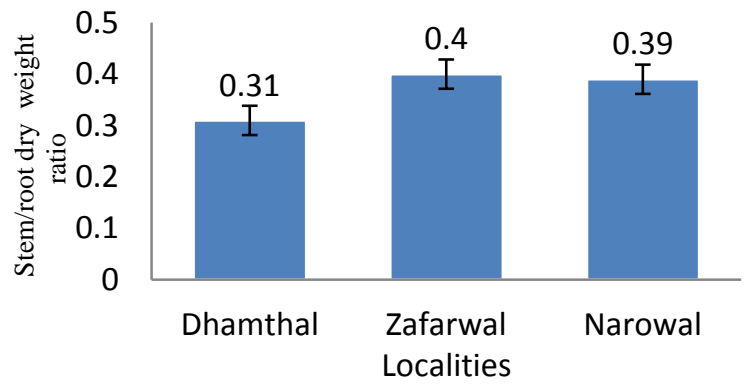

Figure 3. Stem/root dry weight ratio of water hyacinth under different localities

\section{Root moisture percentage}

It was found from results that the average root moisture percentage under all studied treatments was recorded as $91.650 \pm 0.0809 \%$. The lower value of coefficient of variation $(0.15 \%)$ for root moisture percentage indicated that there was consistency among the results which also cleared that the results were reliable for plant of water hyacinth under different localities (Table 1). In Dhamthal moisture percentage was $(90.064 \%)$. In Zafarwal moisture percentage was $(93.75 \%)$ and in Narowal moisture percentage was $(91.5 \%)$ (Figure 4). The higher root moisture percentage revealed that the hyacinths plants may survive under harsh conditions because of higher storage ability of roots (Idrees et al., 2017; Marin et al., 1993).

\section{Stem moisture percentage}

It was found from results that the average stem moisture percentage under all studied treatments was recorded as $92.097 \pm 0.0437 \%$. The lower value of coefficient of variation $(0.08 \%)$ for stem moisture percentage indicated that there was consistency among the results which also cleared that the results were reliable for plant of water hyacinth under different localities (Table 1). In Dhamthal moisture percentage was $(90.064 \%)$. In Zafarwal moisture percentage was $(93.75 \%)$ and in Narowal moisture percentage was $(95.5 \%)$ (Figure 5). The higher root moisture percentage revealed that the hyacinths plants may survive under harsh conditions because of higher storage ability of stem (Mahmood et al., 2005; Tiwari et al., 2007).

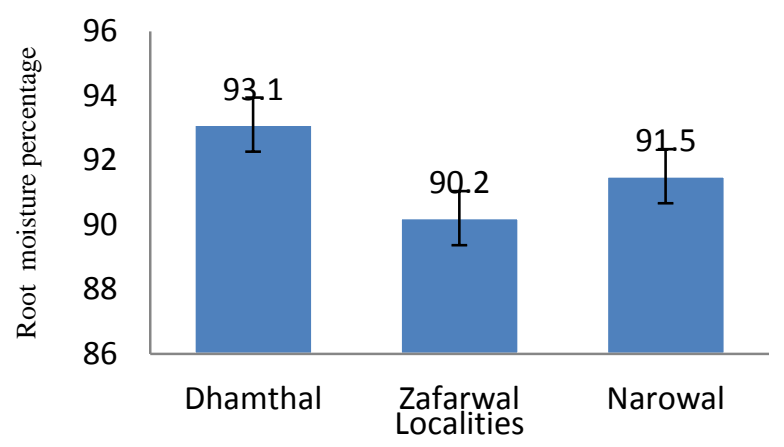

Figure 4. Root moisture percentage of water hyacinth under different localities

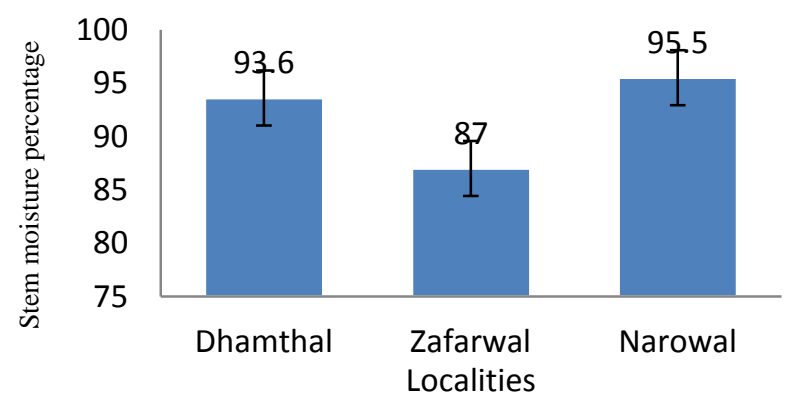

Figure 5. Stem moisture percentage of water hyacinth under different localities

Table 1. Analysis of variance for various morphological traits of water hyacinths

\begin{tabular}{|l|l|l|l|l|l|}
\hline Source & $\begin{array}{l}\text { Stem moisture } \\
\mathbf{\%}\end{array}$ & $\begin{array}{l}\text { Root moisture } \\
\text { \% }\end{array}$ & $\begin{array}{l}\text { Stem/root dry } \\
\text { weight ratio }\end{array}$ & $\begin{array}{l}\text { Stem/root fresh } \\
\text { weight ratio }\end{array}$ & $\begin{array}{l}\text { Plant Height } \\
\text { cm }\end{array}$ \\
\hline Replication & 0.0043 & 0.03687 & 0.00004 & 0.00001 & 0.0221 \\
\hline Locality & $60.5133^{*}$ & $6.3135^{*}$ & $0.00680^{*}$ & $0.07874^{*}$ & $16.3878^{*}$ \\
\hline
\end{tabular}

[Citation: Nazir, M.I., Idrees, I., Danish, P., Ahmad, S., Ali, Q., Malik, A. (2020). Potential of water hyacinth (Eichhornia crassipes L.) for phytoremidation of heavy metals from wastewater. Biol. Clin. Sci. Res. J., 2020: 6. doi: https://doi.org/10.54112/bcsrj.v2020i1.6] 


\begin{tabular}{|l|l|l|l|l|l|}
\hline Error & 0.0057 & 0.01961 & 0.00005 & 0.00001 & 0.1711 \\
\hline Grand Mean & 92.097 & 91.60 & 0.3769 & 0.3478 & 35.244 \\
\hline CV \% & 0.08 & 0.15 & 1.93 & 0.96 & 1.17 \\
\hline Standard error & 0.0437 & 0.0809 & 0.00419 & 0.00192 & 0.2388 \\
\hline
\end{tabular}

Heavy metals concentration in plant and water samples

\section{Cadmium}

The various metals assayed in the experiment were found present in test plants and water samples. However, the concentration of the metals e.g. Cadmium, Arsenic and Mercury in the test plants differed significantly when compared to the different localities as well as the concentration of the metals Cadmium, Arsenic and Mercury in the test water samples differed significantly when compared to different localities. In figure 6 indicate that Cadmium found in plant and water sample according to different localities (Dhamthal, Zafarwal, Narowal). In Dhamthal cadmium in water sample was $(0.00 \mathrm{ppm})$ and in plant sample was (0.002ppm). In Zafarwal cadmium in water sample is $(30.25 \mathrm{ppm})$ and (29.25ppm) in plant sample. In Narowal cadmium metal in water sample is $(177.25 \mathrm{ppm})$ and in plant sample was (166.25ppm).

\section{Arsenic}

In figure 7 indicate that in Dhamthal arsenic in water sample was $(0.04 \mathrm{ppm})$ and in plant sample was $(0.09 \mathrm{ppm})$. In Zafarwal arsenic in water sample was $(0.03 \mathrm{ppm})$ and $(0.02 \mathrm{ppm})$ in plant sample. In Narowal arsenic metal in water sample is $(0.012 \mathrm{ppm})$ and in plant sample was $(0.025 \mathrm{ppm})$.

\section{Mercury}

In figure 8 indicate that in Dhamthal mercury from water sample was $(0.00 \mathrm{ppm})$ and in plant sample was $(0.05 \mathrm{ppm})$. In Zafarwal mercury in water sample was (28.23ppm) and $(0.04 \mathrm{ppm})$ in plant sample. In Narowal mercury metal in water sample was
The findings of the current research (Figures 6, 7 and 8 ) showed that the water hyacinth can bioaccumulate some of these metals under separate localities (Dhamthal, Zafarwal, Narowal), such as cadmium, arsenic and mercury (Carbonell et al., 1998; El-Gendy et al., 2006; Ingole and Bhole, 2003; Mahmood et al., 2005; Upadhyay and Tripathi, 2007; Zhu et al., 1999). In figure 6 indicate that cadmium concentration in Dhamthal was very low in plant sample is $(0.002 \mathrm{ppm})$ as well as cadmium metal not found in water sample this means that the water of Dhamthal contain very lower concentration of cadmium. The amount of cadmium were lower than those reported in literature (El-Gendy et al., 2006; Téllez et al., 2008). The amount of cadmium were higher than those reported in (Marin et al., 1993; Upadhyay and Tripathi, 2007). In figure 7 indicate that arsenic concentration in Dhamthal is very high in plant sample was $(0.09 \mathrm{ppm})$ as well as arsenic metal found in water sample is $(0.04 \mathrm{ppm})$ this means that the water of Dhamthal very polluted which contain very higher concentration of arsenic. The amount of arsenic were lower than those reported in literature (Mahmood et al., 2005). The amount of arsenic were higher than those reported in (Marin et al., 1993). In figure 8 indicate that mercury concentration in Dhamthal is very low in plant $(0.05 \mathrm{ppm})$ and in water mercury not found means that water of Dhamthal contains very low amount of mercury. The amount of mercury were lower than those reported in literature (Abedin et al., 2002).

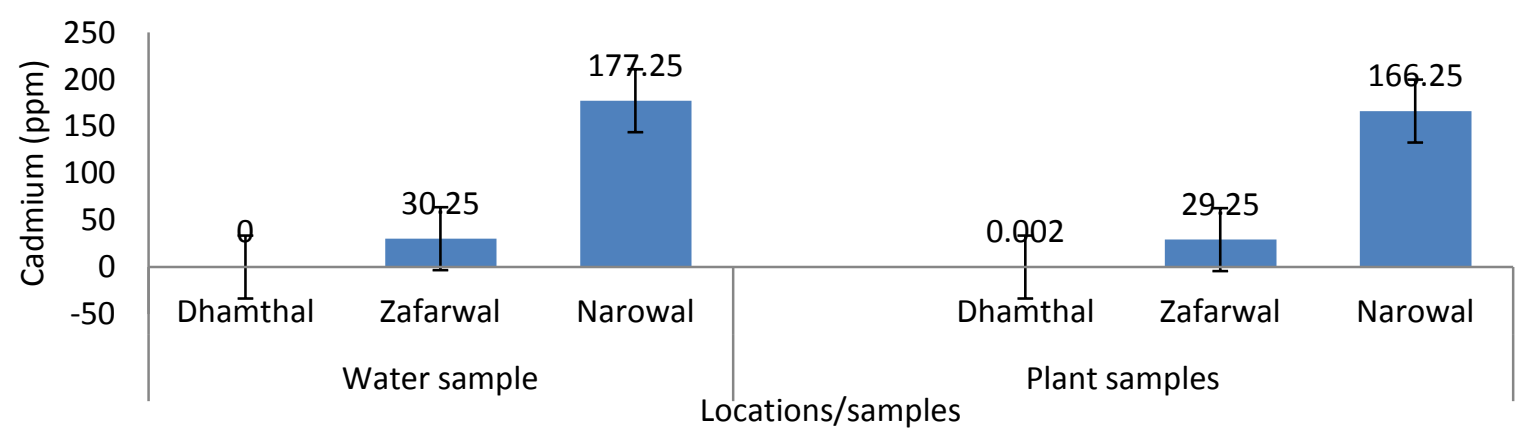

Figure 6. Cadmium concentration in water and plants sample under different localities

[Citation: Nazir, M.I., Idrees, I., Danish, P., Ahmad, S., Ali, Q., Malik, A. (2020). Potential of water hyacinth (Eichhornia crassipes L.) for phytoremidation of heavy metals from wastewater. Biol. Clin. Sci. Res. J., 2020: 6. doi: https://doi.org/10.54112/bcsrj.v2020i1.6] 


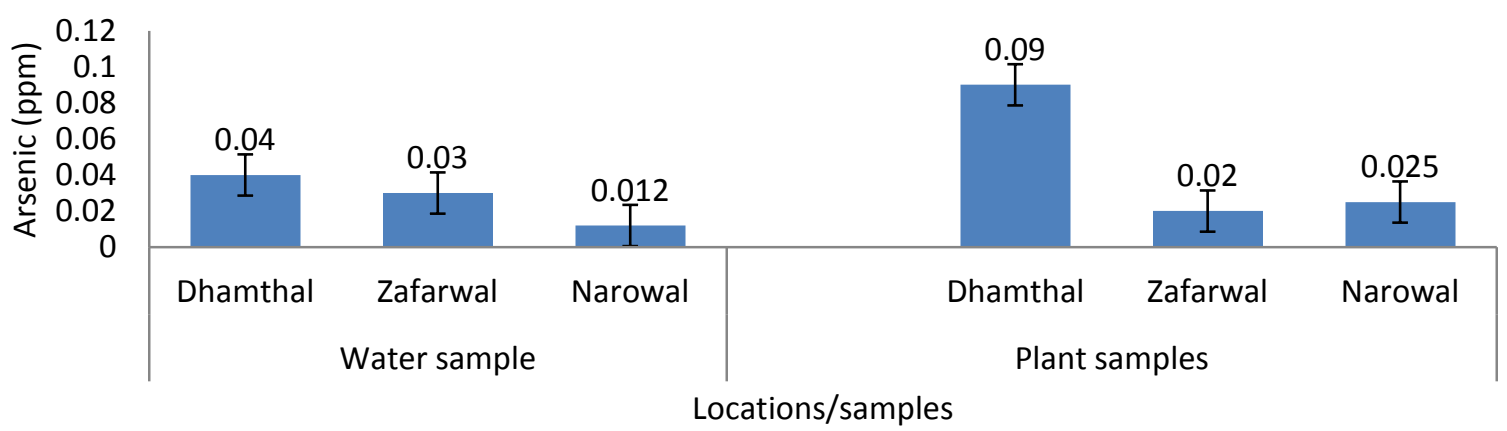

Figure 7. Arsenic concentration in water and plants sample under different localities

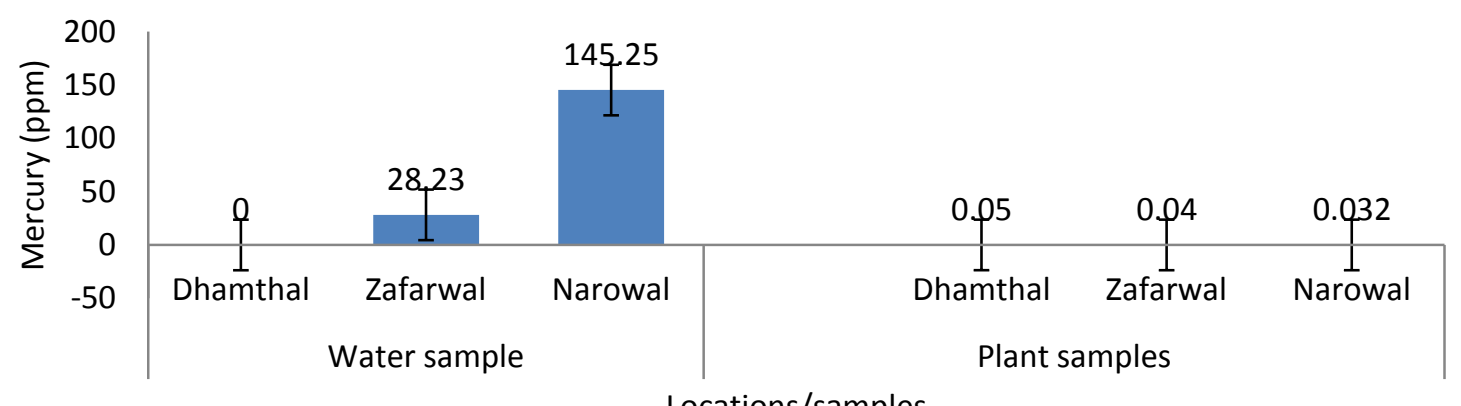

\section{Conclusion}

Phytoremediation is a remediation technology that uses green plants to clean up contaminants from the atmosphere. Phytoremediation can be an option to treat heavy metal contaminated regions as a green technology. According to our research, water hyacinth plant has a strong potential as a bioaccumulator of heavy metals and can be used for heavy metal phytoremediation. Our findings have shown the various options of using water hyacinth to remove pollutants in waste water. It has been found that water hyacinth is appropriate for managing urban waste water. It has also been shown that water hyacinth among aquatic plants is a reasonable and feasible way to absorb toxic nutrients and improve the quality of the water. The research showed that water hyacinth (Eichhornia crassipes) could efficiently phytoremediate contaminated water containing metals such as cadmium $(\mathrm{Cd})$, arsenic (Ar) and mercury $(\mathrm{Hg})$, thereby decreasing the potential environmental danger from untreated waste water to the environment. According to our study the water hyacinth uptake highest amount of metal per dry weight of water hyacinth was $166.25 \mathrm{ppm}$ for cadmium while lowest, $0.032 \mathrm{ppm}$ for mercury. It was suggested from our study that the water hyacinth (Eichhornia crasssipes) uptake cadmium $(\mathrm{Cd})$ metal from sewage water in highest amount as compare to arsenic and mercury. Future research will explore the

Locations/samples

[Citation: Nazir, M.I., Idrees, I., Danish, P., Ahmad, S., Ali, Q., Malik, A. (2020). Potential of water hyacinth (Eichhornia crassipes L.) for phytoremidation of heavy metals from wastewater. Biol. Clin. Sci. Res. J., 2020 : 6. doi: https://doi.org/10.54112/bcsrj.v2020i1.6] 
Dushenkov, S. (2003). Trends in phytoremediation of radionuclides. Plant and soil 249, 167-175.

El-Gendy, A., Biswas, N., and Bewtra, J. (2006). Municipal landfill leachate treatment for metal removal using water hyacinth in a floating aquatic system. Water environment research 78, 951-964.

Erakhrumen, A. A., and Agbontalor, A. (2007). Phytoremediation: an environmentally sound technology for pollution prevention, control and remediation in developing countries. Educational Research and Review 2, 151-156.

Ghosh, M., and Singh, S. (2005). A review on phytoremediation of heavy metals and utilization of it's by products. Asian J Energy Environ 6, 18.

Idrees, I., ZA, A., Ali, Q., Shahid, H., and JA, A. (2017). Accumulation and effects of $\mathrm{Pb}, \mathrm{Cr}$ and $\mathrm{Cd}$ on growth of Zea mays seedlings. International Journal of Biology, Pharmacy and Allied Sciences 6, 1045-1059.

Ingole, N., and Bhole, A. (2003). Removal of heavy metals from aqueous solution by water hyacinth (Eichhornia crassipes). Journal of Water Supply: Research and TechnologyAQUA 52, 119-128.

Mahmood, Q., Zheng, P., Islam, E., Hayat, Y., Hassan, M., Jilani, G., and Jin, R. (2005). Lab scale studies on water hyacinth (Eichhornia crassipes Marts Solms) for biotreatment of textile wastewater. Caspian Journal of Environmental Sciences 3, 83-88.

Marin, A., Masscheleyn, P., and Patrick, W. (1993). Soil redox-pH stability of arsenic species and its influence on arsenic uptake by rice. Plant and Soil 152, 245-253.

Rulkens, W., Tichy, R., and Grotenhuis, J. (1998). Remediation of polluted soil and sediment: perspectives and failures. Water Science and Technology 37, 27-35.

Salt, D. E., Blaylock, M., Kumar, N. P., Dushenkov, V., Ensley, B. D., Chet, I., and Raskin, I. (1995). Phytoremediation: a novel strategy for the removal of toxic metals from the environment using plants. Bio/technology 13, 468-474.

Soomro, M., Khokhar, M., Hussain, W., and Hussain, M. (2011). Drinking water Quality challenges in Pakistan. Pakistan Council of Research in Water Resources, Lahore, 17-28.

Téllez, T. R., López, E., Granado, G. L., Pérez, E. A., López, R. M., and Guzmán, J. M. S. (2008). The water hyacinth, Eichhornia crassipes: an invasive plant in the Guadiana River Basin (Spain). Aquatic Invasions 3, 42-53.

Tiwari, S., Dixit, S., and Verma, N. (2007). An effective means of biofiltration of heavy metal contaminated water bodies using aquatic weed Eichhornia crassipes. Environmental monitoring and assessment 129, 253-256.

Upadhyay, A. R., and Tripathi, B. (2007). Principle and process of biofiltration of $\mathrm{Cd}, \mathrm{Cr}, \mathrm{Co}, \mathrm{Ni}$ $\& \mathrm{~Pb}$ from tropical opencast coalmine effluent. Water, air, and soil pollution 180, 213-223.

Zhu, Y., Zayed, A., Qian, J. H., De Souza, M., and Terry, N. (1999). Phytoaccumulation of trace elements by wetland plants: II. Water hyacinth. Journal of environmental quality $\mathbf{2 8 ,}$ 339-344.

Zubair, M., Shakir, M., Ali, Q., Rani, N., Fatima, N., Farooq, S., Shafiq, S., Kanwal, N., Ali, F., and Nasir, I. A. (2016). Rhizobacteria and phytoremediation of heavy metals. Environmental Technology Reviews 5, 112119.

\section{(c) (†) (8)}

Open Access This article is licensed under a Creative Commons Attribution 4.0 International License, which permits use, sharing, adaptation, distribution and reproduction in any medium or format, as long as you give appropriate credit to the original author(s) and the source, provide a link to the Creative Commons licence, and indicate if changes were made. The images or other third party material in this article are included in the article's Creative Commons licence, unless indicated otherwise in a credit line to the material. If material is not included in the article's Creative Commons licence and your intended use is not permitted by statutory regulation or exceeds the permitted use, you will need to obtain permission directly from the copyright holder. To view a copy of this licence, visit http://creativecommons.org/licen ses/by/4.0/.

(C) The Author(s) 2021

[Citation: Nazir, M.I., Idrees, I., Danish, P., Ahmad, S., Ali, Q., Malik, A. (2020). Potential of water hyacinth (Eichhornia crassipes L.) for phytoremidation of heavy metals from wastewater. Biol. Clin. Sci. Res. J., 2020 : 6. doi: https://doi.org/10.54112/bcsrj.v2020i1.6] 